\title{
INDEPENDENSI MEDIA TEMPO DAN PENGARUH EKONOMI POLITIK DALAM PRAKTIK STRUKTURASI
}

\author{
Elik Susanto \\ Universitas Paramadina Jakarta - Indonesia \\ elik.susanto@gmail.com
}

\begin{abstract}
This research focused on how Tempo editors apply the principles of independence, maintain credibility, and maintain the integrity of journalists as a media business strategy in the digital age. It is no secret that in the media newsroom there are often conflicts, namely the pull between business interests and editorial attitudes. The opposition heats up as newsroom authorities deal with marketing, advertising sections, business development sections, as well as shareholders in news products. The purpose of this study is to see how the negotiation process and compromise the interests of it. At the end of the day, there are those who win and lose. Research using qualitative method with descriptive approach. In describing the findings, researchers will use inductive theory as a tool of hypothesis, observation, and analysis of Tempo practices applying independence in the influence of political economy structure. The researchers' findings state that in maintaining integrity as an effort to uphold the independence of Tempo is not easy to intervene by anyone when making a report on journalistic products.
\end{abstract}

Keywords: Tempo media independence, political economic influence, structuralization practices.

\begin{abstract}
Abstrak
Penelitian ini memfokuskan pada bagaimana redaksi Tempo menerapkan prinsip independensi, mempertahankan kredibilitas, dan menjaga integritas wartawannya sebagai strategi bisnis media di era digital. Sudah bukan rahasia bahwa di ruang pemberitaan media sering terjadi konflik, yaitu tarik menarik antara kepentingan bisnis dan sikap redaksi. Pertentangan memanas manakala otoritas newsroom berhadapan dengan bagian pemasaran, bagian iklan, bagian pengembangan bisnis, juga pemegang saham atas produk berita. Tujuan dari penelitian ini untuk melihat bagaimana proses negosiasi dan kompromi kepentingan itu. Ujungnya ada pihak yang menang dan kalah. Penelitian menggunakan metode kualitatif dengan pendekatan deskriptif. Dalam mendeskripsikan temuan, peneliti akan memakai teori induktif sebagai alat hipotesis, pengamatan, dan analisis praktik Tempo menerapkan independensi dalam pengaruh ekonomi politik strukturasi. Temuan peneliti menyebutkan, dalam menjaga integritas sebagai upaya menegakkan independensi, Tempo tidak mudah diintervensi oleh siapapun ketika membuat laporan produk jurnalistiknya.
\end{abstract}

Kata kunci: Independensi media Tempo, pengaruh ekonomi politik, praktik strukturasi.

\section{PENDAHULUAN}

Pers atau media massa yang ideal menjadi dambaan masyarakat di negara demokratis seperti Indonesia. Dambaan yang dimaksud yaitu media sungguh-sungguh menyuarakan aspirasi publik, menghormati hak asasi, menghargai keberagaman, mengedepankan menginformasikan suatu kebenaran, menebarkan nilai-nilai kebaikan, mengedukasi, serta menyuguhkan konten hiburan. Media dikenal dan dibutuhkan publik karena menyuarakan informasi yang benar dengan prinsip independen. Prinsip independen media terbangun lewat kerja jurnalis yang profesional. Wartawan memiliki kebebasan dalam bekerja ${ }_{s}$ tidak terikat, merdeka, dan mandiri (KBBI Daring). Sehingga independen di sini dapat diartikan media massa dan jurnalisnya bebas dari bentuk campur tangan apapun dari siapapun.

Harapan khalayak yang begiru besar terhadap media di atas muncul karena mempersepsi surat kabar, televisi, dan radio

Submitted: February 2021, Accepted: March 2021, Published: March 2021 
sebagai sarana komunikasi yang dapat dipercaya dan memiliki berbagai kelebihan dibanding medium lain. Realitasnya media dalam konteks ekonomi politik komunikasi tidak dapat dipisahkan dari bisnis. Media massa merupakan ladang investasi sebagaimana perusahaan lain (Mosco, 2006). Di antara ciri-cirinya adalah bisnis media gencar membangun organisasi, menyusun struktur, menghimpun modal, merekrut pekerja, merebut konsumen serta menyusun variabel biaya operasional (McQuail, 2018). Infrastruktur ini diciptakan tidak sekadar upaya media untuk eksis, tapi juga sebagai instrumen komersialisasi bahkan konglomerasi. Komersialisasi dan konglomerasi dapat diartikan upaya strategis dan sistematis membangun media guna memenuhi kebutuhan audiens atau konsumen sehingga menghasilkan profit.

Bagaimana berita diproduksi secara independen, kontinyu, memenuhi kebutuhan khalayak dan berelasi dengan bisnis? Teori tindakan sosial strukturasi memberikan gambaran bagaimana proses itu berlangsung. Pengaruh strukturasi ini merujuk pada sosiolog Anthony Giddens, yang menjelaskan bahwa industri informasi dan komunikasi yang di dalamnya ada media merupakan kegiatan sosial atau tradisi sosiocultural. Pada aktivitas sosial terdapat peran dua komponen yaitu agen dan struktur yang saling membangun relasi melintasi ruang dan waktu (Giddens, 1990).

Agen dalam strukturasi adalah pelaku baik itu individu, kelompok, organisasi, perusahaan dan lainya yang disebut juga sebagai aktor. Sedangkan struktur dalam teori strukturasi wujudnya berupa aturan-aturan dan sumber daya yang dimanfaatkan agen untuk berinteraksi. Struktur (ruler) dalam organisasi formal seperti perusahaan media massa bentuknya bisa berbagai rupa. Di antaranya buku pedoman karyawan, Kode Etik Jurnalistik bagi tim redaksi, nilai-nilai internal perusahaan misalnya budaya perusahaan, serta prosedur kerja atau SOP (Standard Operating Procedure).
Media massa di Indonesia seperti televisi, radio, portal berita, surat kabar, majalah, tabloid, dan media baru dalam berbagai platform adalah agen. Sedangkan regulasi seperti Kode Etik Jurnalistik, Undang Undang tentang Pers, Undang Undang tentang Penyiaran serta sejumlah pedoman atau aturan yang dikeluarkan Dewan Pers adalah bagian dari struktur. Keduanya, agen dan struktur, merupakan dualitas yang saling berkaitan. Hubungan timbal balik ini menjadikan struktur tidak pernah ada tanpa agen, begitu pula agen tidak dapat berperan tanpa struktur.

Apabila dikaitkan dengan standar idealisme media, Giddens membagi tiga unsur mengenai strukturasi, yaitu interpretation (pemahaman), morality (konsep ideal), dan power (kekuasaan). Tiga unsur ini, keberadaan agen diwajibkan mengetahui atau memahami adanya aturan main (pemahaman), langkah apa saja yang ditempuh sesuai (konsep ideal) dan bagaimana aturan main itu ditaati atau dijalankan (kekuasaan). Komponen inilah yang kemudian dipakai kelompok dominan mempertahankan struktur lewat aturan-aturan tersebut.

Dalam perkembangannnya, teori strukturasi Giddens dipengaruhi oleh ilmu ekonomi politik komunikasi Vinvent Mosco. Melalui bukunya The Political Economy of Communication, Mosco (2006) mengatakan strukturasi berkaitan dengan ekonomi politik dan pembentukan konsep kelas sosial, gender, dan ras. Konsep kelas dapat mengubah perilaku agen sebagai aktor dalam berinteraksi dengan struktur. Interakti yang terus berulang oleh aktor menimbulkan sebab akibat pada struktur, sehingga terjadi proses produksi dan reproduksi sosial agen.

Praktik strukturasi pada akhirnya menghasilkan atau lebih tepatnya memunculkan hegemoni. Hegemoni dalam konteks strukturasi adalah saling mempengaruhi antara ideologi satu dengan ideologi yang lain. Saling mempengaruhi inilah kemudian dipersepsikan khalayak. Publik yang terhegemoni tidak merasakan adanya paksaan atau instruktisonal. Hegemoni 
menyebabkan individu tidak membutuhkan lagi informasi sesungguhnya. Hegemoni yang digagas oleh Antonio Gramsci dapat diartikan sebagai kekuatan sosial.

Hegemoni tercipta melalui proses di mana masyarakat mengalami situasi "blok historis", yaitu praktik penundukan dan persetujuan secara terus menerus. Blok historis adalah proses timba balik (resiprokal) antara aktivitas etik, politik, ideologis serta ekonomi di antaranya oleh informasi dan produk media. Dengan demikian hegemoni tercipta karena adanya penekanan dari kelompok yang mendominasi kepada kelompok yang didominan. Kelompok dominan berhasil menghegemoni (menciptakan) wacana di masyarakat, sehingga khalayak tidak merasa dikendalikan cara berfikirnya oleh kelompok dominan. Menurut Gramsci dalam Douglas Kellner, pers atau media merupakan bagian dari kelompok yang mendominasi ideologi tatanan sosial.

Ruang redaksi media (televisi, radio, surat kabar, website, media baru) seharusnya steril dari kepentingan apapun ketika memproduksi berita. Namun media yang terkena pengaruh ekonomi politik komunikasi mengalami komodifikasi dan spasialisasi (Mosco, 2006). Komodifikasi adalah proses transformasi barang dan jasa dari nilai guna ke nilai tukar. Barang dan jasa tersebut sebagai komoditas yang bisa diperjualbelikan. Dalam bisnis media massa, proses transformasi ini melibatkan semua komponen yang berkepentingan, mulai dari awak redaksi, pembaca, pasar, dan juga negara dalam bentuk regulasi.

Sedangkan spasialisasi adalah proses transformasi yang bertujuan mengatasi hambatan ruang dan waktu. Dalam praktik ekonomi kapitalisme saat ini, spasialisasi merupakan upaya media massa untuk membangun pengaruh lebih luas. Caranya, media membentuk korporasi atau badan usaha baik bersifat horizontal maupun vertikal. Perkembangan teknologi digital sangat berperan memuluskan praktik spasialisasi media masa karena dengan mudah memperlebar jaringan kerja sama yang ujungnya berpengaruh pada bertambahnya profit.

Masalahnya, muncul persepsi publik bahwa demi profit perusahaan mudah mengendalikan ruang pemberitaan. Pengendalian dapat diartikan sebagai campur tangan kepentingan bisnis ke jajaran redaksi, sehingga media tidak lagi mampu menjaga independensinya. Fenomena pemilik modal menentukan arah kebijakan redaksi dialami oleh banyak media. Sebagian khalayak kemudian memakluminya. Semua seolah-olah wajar-wajar saja. Persepsi publik kian meluas menyangkut loyalitas jurnalis dalam membuat berita. Kerja wartawan dianggap tidak mengutamakan kepentingan publik. Orientasi kerja media tunduk kepada kekuatan ekonomi yaitu pemilik perusahaan yang mengutamakan keuntungan finansial, sedangkan independensi dalam memperoduksi berita dinomorduakan.

Berita adalah materi yang dikonsumsi khalayak atas peristiwa di luar pengetahuan mereka. Kualitas berita menjadi penting dengan didukung oleh akurasi yang dapat dipertanggungjawabkan. Itulah perlunya dapur pemberitaan berikut jurnalisnya memiliki independensi dalam menentukan arah pemberitaan medianya. Tidak boleh ada pihak luar mengintervensi atau mencampuri urusan dapur redaksi. Kebebasan sebagai prinsip kerja media, yaitu independen guna mejaga kepercayaan kepada audiens (McQuail 2006).

Prinsip ini telah menjadi bagian dari kode etik sebagai bentuk (struktur). Apabila jurnalis sebagai agen tidak menjalankannya, maka bisa dikategorikan wartawan tidak mentaati etika profesi dan medianya diragukan kredibilitasnya. Namun, dalam praktiknya independensi dalam sebuah newsroom sulit diaplikasikan oleh media karena adanya kepentingan lain yang saling tarik menarik. Misalnya bidang iklan, sirkulasi, dan juga berkaitan dengan kerja sama perusahaan menjalankan bisnis antarjaringan media.

Keputusan yang disusun redaksi media sangat mungkin dipengaruhi oleh faktor lain seperti kepentingan bisnis dan pemgaruh 
dominasi kekuatan internal dan eksternal (Mosco, 2006). Dominasi kekuasaan internal yaitu pemilik modal dan pengelola media itu sendiri. Sedangkan pengaruh eksternal bisa datang dari masyarakat yang mendistorsi ruang pemberitaan. Walaupun, proses produksi berita merstinya terlindungi dari berbagai pengaruh. Perlindungan tersebut berupa landasan moral dan etika profesi. Supaya media mendapat kepercayaan publik, jurnalis harus memiliki kapabilitas, integritas, dan profesional. Wartawan juga dipastikan mentaati Kode Etik Jurnalistik (LPDS, 2019). Hanya dengan cara inilah independensi media bisa dijaga dan diimplementasikan.

Landasan moral dan etika profesi watawan Indonesia, yaitu Kode Etik Jurnalistik yang terdiri dari 11 pasal. Pada pasal 1 terdapat 3 bagian penting yang berhubungan dengan kebenaran berita jurnalistik. Pertama independen, maksudnya memberitakan peristiwa atau fakta tanpa ada campur tangan, paksaan dan intervensi dari pihak lain termasuk pemilik perusahaan pers. Kedua akurat, artinya jurnalis dalam membuat laporan isinya bisa dipercaya dan obyektif. Ketiga berimbang yang berarti semua pihak mendapat kesempatan dalam pemberitaan. Wartawan media tidak boleh mempunyai itikad buruk dan niat menimbulkan kerugian pihak lain.

Fenomena ruang pemberitaan yang menjadi bahan analisa penulisan artikel ini adalah proses produksi berita di dapur redaksi Tempo Media Group. Selain observasi newsroom, peneliti juga menelaah mekanisme peliputan, perumusan angle atas sebuah peristiwa, bagaimana berita dilaporkan, ditulis, proses editing, hingga artikel siap ditayangkan dalam berbagai platform. Observasi dan menelaah mekanisme kerja untuk mengetahui apakah proses strukturasi terjadi atau tidak dalam newsroom Tempo.

Peneliti menyadari kajian dan penelitian mengenai tema independensi media sudah banyak dilakukan serta dipublikasikan di berbagai jurnal. Namun, perkembangan bisnis media dan kerja jurnailstik sangat dinamis, sehingga tidak akan habis bagi kalangan akademik untuk menelaah dari sudut pandang lain serta pendekatan berbeda.

Beberapa contoh jurnal mengenai tema independensi di antaranya mempertanyakan kesanggupan wartawan menjalankan prinsip independen (Musfialdy, 2019). Kemudian jurnal yang menyoroti kepemilikan media sebagai aksi korporasi (Nursatyo, 2012). Walaupun banyak yang menentang, tapi praktik pembelian banyak media yang memunculkan dominasi kepemilikan satu orang, sebagai konsekuensi pengaruh kapitalisme global dan ini tak dapat dihentikan.

Sedangkan alasan peneliti untuk mengangkat topik independensi media sebagai berikut. Dari jurnal dan tesis yang lebih dulu ada tidak ditemukan penggambaran bagaimana terjadinya konflik di ruang redaksi sebagai pengaruh dari berbagai pendekatan teori. Newsroom yang pada dasarnya independen dalam organisasi media massa seolah-olah tidak berbuat apa-apa atau tidak berkutik ketika terjadi komodifikasi, spasialisasi maupun strukturasi. Pembahasan tentang bagaimana gejolak ruang pemberitaan dan bagaimana kebijakan perusahaan media, merupakan celah bagi penelitian ilmu komunikasi. Masalah tersebut yang membedakan dengan penelitian sebelumnya dan peneliti akan menjabarkan temuannya.

\section{METODOLOGI PENELITIAN}

Penelitian ini menggunakan metode kualitatif sebagai upaya untuk memahami secara mendalam dan menyeluruh praktik kerja media. Fokus penelitian yaitu mendeskripsikan secara lengkap dan mendalam atas fenomena kerja media massa, khususnya dapur redaksi. Peneliti dilakukan dengan cara interaksi dan pengamatan terhadap obyek yang diteliti guna memperoleh pengalaman guna memperkuat intepretasi serta analisa dengan pendekatan induktif. Motode penelitian kualitatif di sini, seperti dijelaskan Sarah J. Tracy (2013), menekankan bagaimana konsentrasi kegiatan peneliti pada tindakan 
dan struktur, memeriksa data sejarah, serta kontroversi yang melatari metodologi.

Karaktersitik penelitian kualitatif berkaitan dengan tindakan dan struktur dalam buku dapat dipahami melalui dua cara (Tracy, 2013). Pertama, penelitian kualitatif menyelidiki tindakan melalui pemeriksaan ketat terhadap praktik sehari-hari obyek yang ditelititi. Obyek yang dimaksud dalam penelitian ini adalah ruang redaksi media. Cakupannnya meliputi bagaimana sikap dan kebijakan media atas sebuah peristiwa, bagaimana membangun logika, serta bagaimana merumuskan argumentasi. Peneliti menggunakan pengamatan sebagai panduan membuat premis.

Kedua, peneliti memeriksa struktur sebagai sistem yang mempengaruhi tindakan. Apakah struktur mendomonasi tindakan ruang redaksi menyangkut ideologi, terkait dengan asumsi kebenaran, sampai dengan wacana kekuasaan. Inti dari pemahaman ini penelitian kualitatif menyoroti keberadaan struktur. Secara teori kekuatan penelitian dengan pendekatan induktif mengacu pada apa yang terjadi di lapangan. Pendekatan induktif memberi peluang peneliti untuk memahami arti aturan organisasi dan perilaku anggota tim redaksi. Sehingga peneliti dituntut untuk observasi detail.

Ada empat unsur penting penelitian kualitatif dengan pendekatan induktif (Tracy, 2013). Pertama memulai dengan interaksi dan proses pengamatan secara khusus untuk mendapatkan cerita detail. Ketika merumuskan sebuah pemberitaan, media menerapkan mekanisme penentuan tema dan angle (sudut pandang) yang dipengaruhi oleh budaya (emik) kerja. Di sini peneliti perlunya melihat langsung proses kerja dengan memperhatikan percakapan, menganalisis data kemudian mendokumentasikan. Dari rangkaian ini peneliti membuat klaim tentang pola kerja redaksi. Studi ini bisa disebut dengan inkuiri empiris, yaitu melihat fenomena proses kerja organisasi yang sudah matang dalam membuat kebijakan (Yin, 2003).
Kedua mengkonsep pola umum dari proses pengamatan yang dibangun lewat observasi apa yang menjadi tren, pendalaman masalah dengan wawancana, serta dokumentasi. Selanjutnya peneliti mengklasifikasi dan mengagregasi data yang terkumpul. Melalui agregasi inilah peneliti merangkai temuan yang terpisah-pisah menjadi satu pola umum. Data lapangan selanjutnya diorganisasi secara kronologis dan dikategorisasi berdasarkan tipologi (Yin, 2003).

Ketiga menyusun klaim yang bersifat tentatif, tujuannya untuk pemeriksaan ulang di lapangan apabila dibutuhkan. Ruang redaksi media merupakan tempat merumuskan masalah yang bersumber dari usulan para anggota tim pemberitaan. Setiap usulan mendapat porsi sama untuk dibahas secara mendalam dalam sebuah rapat perencanaan. Ketika sebuah usulan diterima dan menjadi keputusan, semua tim redaksi harus mendukung dan menjalankannya. Hasil rapat perencanaan tentu saja masih membutuhkan verifikasi guna mendapatkan penguatan (reinforcement) yaitu mengecekan ulang di lapangan.

Upaya penguatan dan penyempurnaan data di lapangan dengan cara pengecekan ulang biasa disebut dengan pendekatan dari bawah ke atas (botton up). Dalam perumusan kesimpulan, dimulai dari kasus-kasus tertentu yang ditemukan di lapangan, kemudian ditarik ke tingkat abstrak teori (Aminah, 2019). Selanjutnya setelah peneliti mengidentifikasi pola, hasil observasi dapat dirumuskan hipotesisnya untuk diuji. Keempat menarik kesimpulan untuk membangun teori berdasarkan rumusan hipotesis dan pengujian. Di sini peniliti dapat membuat rumusan kesimpulan umum.

Penelitian kualitatif dengan pendekatan analisis logika induktif, di mana silogisme dibangun berdasarkan hal-hal yang khusus berupa data lapangan kemudian bermuara pada hal-hal umum (Bungin, 2017). Dengan demikian, metode analisis kualitatif dipakai untuk memahami sebuah fakta, bukan 
menjelaskan fakta tersebut. Analisis kualitatif berangkat dari pendekatan fenomologisme. Pendekatan ini peneliti dianggap relevan karena fenomologisme memang cocok digunakan untuk mengurai persoalan subyek manusia yang perilakunya cenderung berubahubah, dinamis dan terkadang tidak taat asas.

Mengapa peneliti memilih obyek penelitian Tempo Media Group? Ini sesuai dengan tujuan utama pembahasan yaitu melihat praktik independensi media dan pengaruh ekonomi politik komunikasi dalam teori stukturasi. Tempo dipilih karena memiliki nama kuat sebagai salah satu media arus utama yang memiliki pengaruh besar di Indonesia dan menjadi icon media investigasi. Laporan investigasi menuntut kerja jurnalis lebih keras, jujur, obyektif, dan independen. Kenyataannya tidak banyak media sejenis yang konsisten memperoduksi laporan investigasi seperti Tempo.

Produk investigasi Tempo berbeda dengan jenis laporan berita lainnya. Liputan investigasi membutuhkan waktu, biaya juga risiko keamanan serta keselamatan wartawan. Hal ini tidak lepas dari faktor kepentingan politik dan ekonomi atas obyek atau kasus yang diinvestigasi. Terkadang kasus yang diinvestigasi Tempo berkaitan dengan kepentingan kekuasaan, tokoh, dan juga bisnis yang kebetulan mempunyai relasi perusahaan Tempo. Namun tantangan itu dapat diatasi dengan kerja profesional, yaitu wartawan Tempo mengedepankan akurasi, kebenaran yang teruji secara jurnalistik, klarifikasi, serta obyektif dalam menyajikan laporan.

Sifat penelitian kualilatif yang berfokus pada deskripsi konteks, harus bertumpu pada observasi lapangan dan ini yang membedakan dengan jenis penelitian lainnya seperti penelitian kuantitatif (Tracy, 2013). Ciri-ciri penelitian kualilatif adalah jenis penelitian ilmiah ilmu sosial yang titik penekanannya memahami makna atas sebuah fenomena. Penelitian kualitatif melihat setiap kasus sebagai sesuatu yang bisa dipelajari. Di dalamnya antara lain menyangkut pengelaman orang, adanya kebenaran, dan fakta yang bisa dipelajati oleh peneliti.

Penelitian kualitatif bermuara pada hasil analisis yang deskriptif sehingga dapat dipahami secara mendalam walaupun pada umumnya penelitian kualitatif tidak dapat digeneralisasikan karena terkait dengan sudut pandang peneliti. Penelitian kualitatif membuka ruang penelitian lanjutan atas tema yang sama dengan temuan serta sudut pandang berbeda. Selanjutnya menyangkut metode pengumpulan data.

Metode pengumpulan data di antaranya dalam bentuk teknik pengamatan di mana peneliti berada di lolasi obyek yang diobservai. Hal yang mesti dicermati dalam pengamatan adalah poin-poin penting menyangkut perumusan sikap redaksi. Bagaimana usulan disampikan, perumusan masalah, dasar pemikiran dan argumentasi, siapa saja yang berhak mengusulkan topic bahasan, hingga keputusan diambil. Teknik pengumpulan data melalui metode wawancara, yaitu menggali lebih detail atas hasil temuan pengataman. Ini sebagai bentuk cek ulang atas informasi yang peneliti perolah pihak lain. Wawancara dilakukan lebih dari satu kali, bergantung dari kebutuhan pendalaman informasi peneliti.

Berikutnya metode pengumpulan data melalui teknis analisa riwayat atau sejarah (history). Ini merupakan kelanjutan dari teknis wawancara, yang tujuannya mengkonfirmasi kebenaran sikap, perjalanan organisasi, serta catatan penting terkait dengan pengalamanpengalaman sebelumnya. Inti dari pengumpulan data melalui metode analisa history, yaitu membandingkan antara hasil pengamatan dan hasil wawancara dengan berbagai dokumen. Proses ini sekaligus dapat dipakai untuk mengetahui konsistensi atas prinsip, sehingga akan memperkuat kesimpulan peneliti.

Melalui proses ini peneli bisa mendapatkan jawaban atas pertanyaan bagaimana pengaruh ekonomi politik komunikasi terhadap independensi Tempo Media Group dan praktek strukturasi. Melalui 
interaksi, pengamatan, dan wawancara langsung peneliti yang dalam hal ini pernah bekerja di Tempo mendapatkan gambaran riil praktik bagaimana media massa mainstream ini menjaga independensi dan idealisme wartawannya terpelihara. Peneliti juga memanfaatkan data korporasi untuk menelaah struktur organisasi redaksi berikut mekanisme kerja produksi berita Tempo.

Sedangkan fokus observasinya mencermati kerja newsroom, bagaimana independensi ditegakkan di semua platform media dalam jaringan Tempo Media Group. Kebijakan Tempo menjalankan prinsip independen juga mencakup seluruh anak perusahaan. Selain media, Tempo juga mengembangkan bisnis alternatif seperti percetakan PT Temprint, pelatihan jurnalistik dan penulisan artikel untuk publik Tempo Institute, serta konsultan media internal perusahaan dan isntansi atau in house magazine PT Matair. Independensi anak perusahaan yaitu bebas membuat produk kreatif serta leluasa pula menentukan dengan siapa mereka bekerja sama.

Sedangkan jaringan media Tempo meliputi majalah Tempo, Koran Tempo, portal berita Tempo.co serta Pusat Data dan Analisa Tempo. Selain empat jenis media utama ini, Tempo mempunyai sejumlah anak perusahaan yang memanfaatkan teknologi digital. Di antaranya portal berdasarkan segmentasi pembaca seperti otomotif yang diberi nama gooto.com. Laman gaya hidup untuk pembaca perempuan cantika.com.

Berikutnya portal jaringan media Tempo melibatkan berbagai media daerah di seluruh Indonesia, Teras.id. Selain itu terdapat kanal sebagai pengembangan audiens, yaitu cekfakta.tempo.co yang secara khusus memproduksi artikel hasil verifikasi secara digital atas konten hoaks, Tempo Witness sebuah kanal yang memfokuskan isu lingkungan dan sumber daya alam dengan platform jurnalisme masyarakat. Berikutnya kanal video, infografis, kanal data, podcast, dan investigasi. Seluruh institusi media masa ini berada di satu atap Tempo Media Group di Jalan Palmerah Nomor 8 Jakarta Selatan.

\section{HASIL DAN PEMBAHASAN}

\section{Hasil Penelitian}

Kemajuan teknologi informasi dan komunikasi di Indonesia melahirkan berbagai wajah baru media yang tanpa disadari mereduksi kredibilitas, integritas dan profesionalitas pers. Ini ditandai dengan tumbuh subur media partisan, media sensasional, dan media yang terseret dalam menyebarkan berita palsu demi mengejar klik: viewer, user, serta follower. Media semacam ini tidak hanya mendistorsi, tapi sering kali juga menabrak kode etik. Tentu tidak semua media mengikuti arus. Masih banyak media yang bertahan dengan kesadarannya memegang teguh idealisme, salah satunya Tетро.

Tempo dalam menjaga dapur redaksinya tidak bebas dari berbagai campur tangan. Ini terbukti dari sejarah media yang berdiri pada 1971 itu dua kali dicabut izin penerbitannya oleh pemerintahan Orde Baru. Pembredelan atau pencabutan SIUP Tempo pertama pada 1982, kedua pada 1994 karena terkait dengan pemberitaan yang dilaporkan. Pembredelan terakhir buntut dari laporan investigasi pembelian kapal perang bekas dari Jerman Timur. Akibatnya bisnis Tempo dimatikan dan seluruh sumber dayanya hilang. Bisnis perusahaan berhenti mendadak, karyawan dan wartawan menjadi pengangguran.

Intervensi kepada media banyak bentuknya. Seperti budaya telepon aparat ke redaksi Tempo nyaris tak terhitung jumlahnya terkait dengan berita yang dipublikasikannya. Gangguan kebebasan pers setelah reformasi tidak surut, justru datang dari berbagai penjuru. Termassuk dari organisasi sosial kemasyarakatan maupun organisasi yang mengatasnakan agama. Tempo pernah menjadi sasaran unjuk rasa kelompok yang mengatasnamakan Front Pembela Islam (FPI). Mereka datang ke Kantor Tempo dengan 
sepeda motor dan menumpang truk menuntut redaksi meminta maaf atas pemuatan kartun yang dianggap mirip piminan FPI, Rizieq Shihab.

Kosnsekuensi sikap independen itu, redaksi Tempo harus menghadapi berbagai pihak yang tidak puas dan merasa dirugikan oleh pemberitaan media ini. Keputusan rapat redaksi adalah yang tertinggi. Hasil rapat tidak dapat diubah tanpa melalui mekanisme meeting serupa. Produk berita Tempo dirumuskan lewat mekanisme rapat dengan menjaring gagasan anggota redaksi, mulai dari reporter, redaktur, hingga pemimpin redaksi. Semua awak Tempo mulai dari reporter, editor hingga pemimpin redaksi hadir dalam rapat perencanaan konten. Ini dapat disebut sebagai praktik strukturasi di mana agen (tim redaksi) berperan penting dalam pengambilan keputusan yang diatur dalam struktur .

Independensi Tempo diperlihatkan lewat peran para aktor di dapur pemberitaan. Produksi berita dimulai dari perdebatan pandangan mengenai sudut pandang atas sebuah informasi. Ide-ide dalam ruang redaksi diadu. Gagasan yang didukung data, argumentasi dan meberi dampak kepada publik yang biasanya unggul dan kemudian disepakati sebagai keputusan rapat.

Perbedaan sudut pandang antara anggota redaksi sudah lazim dalam raat redaksi. Begitu pula sudut pandang antara satu media dengan media lain, perbedaan tidak bisa dihindari. Sebab, selain karena setiap media memiliki segmentasi pembaca masing-masing, pemilihan sudut pandang merupakan bagian dari kebebasan pers dan implementasi independensi media sebagaimana diatur dalam Kode Etik Jurnalistik.

Berikut ini contoh produk berita Tempo yang bisa dikategorikan sesuai dengan prinsip independensi media massa.

Media Tempo Group pada Pemilu 2014 dipersepsikan oleh publik sikapnya mendukung pasangan Joko Widodo - Jusuf Kalla. Sebaliknya Tempo dinilai tidak menginginkan pasangan Prabowo Subianto Hatta Rajasa. Khalayak dengan mudah menghukum Tempo sebagai media yang tidak netral karena telah berpihak kepada salah satu pasangan. Sikap Tempo tercermin dalam artikel editorial edisi 9 Juli 2014 berjudul "Memilih Pemimpin".

Tempo pada edisi tersebut membangun narasi sikap untuk tidak memilih Prabowo Subianto sebagai presiden karena dianggap oleh media ini memiliki berbagai catatan buruk di masa lampau. Di antaranya dugaan keterlibatan Prabowo dalam kasus pelanggaran hak asasi manusia berat. Pelanggaran HAM yang dituduhkan yaitu keterlibatan dalam penghilangan dan penculikan terhadap sejumlah aktivis pro demokrasi pada 1998. Prabowo seorang perwira tinggi TNI Angkatan Darat yang dipecat. Catatan buruk tersebut dijadikan dalih Tempo menegasikan bahwa Prabowo tidak layak dipilih menjadi pemimpin. Walaupun, Tempo dalam narasi sikapnya ini tidak terus terang mengajak publik untuk memilih Jokowi.

Setelah pasangan Jokowi - Kalla dinyatakan menang atas pasangan Prabowo Hatta, sikap independesi Tempo diuji. Apakah media ini tetap kritis dan obyektif atau justru sebaliknya terhadap pemerintahan JokowiKalla? Sejauh mana Tempo memerankan posisinya sebagai anjing penjaga (watch dog) penguasa? Apakah Tempo sanggup menjaga jarak dengan kekuasaan pemerintahan Jokowi - Kalla, yang dalam proses pemilihannya dipersepsikan memberikan dukungan. Apa ada keuntungan ekonomi atau keuntungan lain Tempo dengan terpilihnya Jokowi - Kalla? Semua itu harus dijawab oleh Tempo lewat produk pemberitaannya yang dikenal kritis dan obyektif. Khalayak menunggunya dan akan menilai apakah Tempo independen atau tidak.

Tempo, sepengetahuan peneliti, dalam menyajikan liputan tidak atas dasar ingin membuktikan tetap independen guna menjawab kekhawatiran publik. Tim redaksi Tempo bekerja selalu berdasarkan fakta yang didukung bukti kuat, akurat, serta terkonfirmasi (cover both side). Laporan Tempo membuktikan tetap independen pada laporan edisi 14 September 2019 berjudul 
"Janji Tinggal Janji" dengan ilustrasi gambar Jokowi berhidung panjang. Publik memahami ilustrasi cover Tempo mirip pinokio. Persepsi publik pun mucul lewat ilustrasi dan judul majalah itu, Jokowi dianggap berbohong. Banyak janji yang diucapkan dalam kampanye Pemilihan Presiden 2014, namun setelah 5 tahun memerintah banyak pula yang tidak dilaksanakan. Salah satunya masalah pemberantasan korupsi.

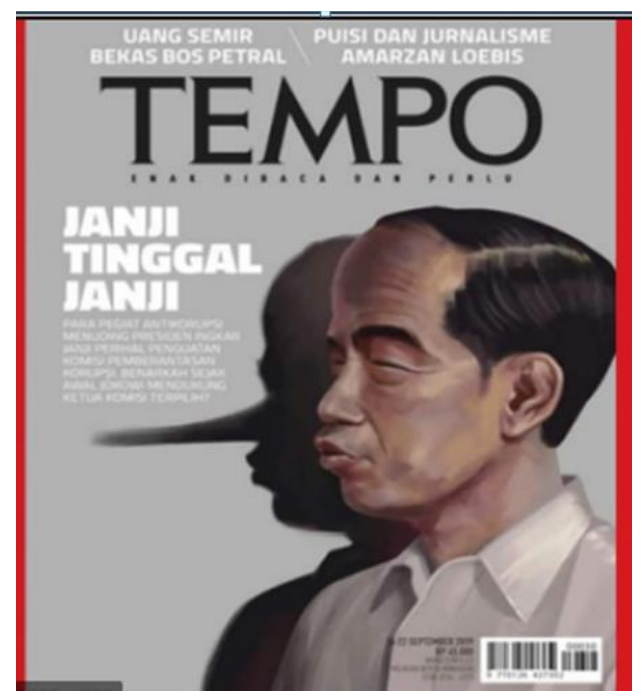

Gambar 1. Cover Majalah Tempo edisi 14-21 September 2019.

Pro dan kontra ilustrasi mengundang keberatan dan kecaman. Tidak sedikit pembaca yang memberi pujian kepada Tempo. Redaktur Eksekutif Majalah Tempo Setri Yasra ketika itu mengatakan bahwa cover yang dimaksud bukan menggambarkan Presiden Jokowi sebagai pinokio (gambar 1). "Tempo tidak pernah menghina kepala negara sebagaimana dituduhkan. Tempo tidak menggambarkan Presiden sebagai pinokio. Yang tergambar adalah bayangan pinokio," kata Setri Yasra yang sekarang menjabat sebagai Pemimpin Redaksi Tempo.co.

Menurut Setri, sampul Tempo dengan judul "Janji Tinggal Janji" itu metafora atas dinamika di masyarakat. Seperti tudingan sejumlah penggiat antikorupsi bahwa Presiden Jokowi ingkar janji dalam penguatan Komisi
Pemberantasan Korupsi (KPK). Publik mencemaskan masa depan pemberantasan korupsi bila Presiden Jokowi membiarkan revisi UU KPK, yang di dalamnya ada upaya pelemahan terhadap lembaga anturasuah itu. Dengan laporan tersebut, independensi Tempo bisa dianggap tetap terjaga. Tidak menutupnutupi kekurangan dan kelamahan pemerintahan Jokowi - Kalla. Tempo tetap cermat dan lugas memotret keresahan masyarakat, walaupun Tempo menghadapi risiko dilaporkan ke Dewan Pers oleh kelompok yang mengatasnamakan relawan Jokowi - Kalla.

Mereka yang mengadu ke Dewan Pers menuduh Tempo telah menghina Presiden Jokowi. Tempo juga dituding mendiskreditkan Presiden karena dalam laporan majalah itu dianggap menggiring opini pemerintahan Jokowi - Kalla tidak berpihak pada pemberantasan korupsi. Tempo mempersilakan pihak yang tidak puas melapor ke Dewan Pers sebagai lembaga yang "mengadili" sengketa pers. Dalih Tempo membuat cover mirip gambar Jokowi sebagai kritik sesuai amanat UU Nomor 40 Tahun 1999 tentang Pers.

Tempo mengklarifikasi bahwa laporannya sudah obyektif dan tidak melanggar Kode Etik Jurnalistik. Ukuran obyektivitas media dalam melaporkan peristiwa tidak dapat dinilai dari pemilihan sudut pandang. Pemilihan sudut pandang atau angle menjadi bagian dari cara kerja media (Kovach \& Rosenstiel, 2003). Oyektivitas pemberitaan harusnya dicermati bagaimana media menyajikan laporan. Apakah prinsip keberimbangan (cover both side) sudah dijalankan atau belum.

Keberimbangan adalah memberi kesempatan ruang konfirmasi kepada dua nara sumber yang bertentangan. Ketaatan media menjalankan keberimbangan inilah publik pembaca bisa menilai pesan dan makna berita yang disiarkan, diberitakan, diperdengarkan obyektif atau tidak. Selain cover both side, akurasi juga tidak kalah penting. Bahkan di internal redaksi Tempo akurasi adalah mahkota jurnalistik. Lantaran sebagai mahkota, maka 
akurasi benar-benar menjadi perhatian ketika mengutip data, dokumen dan melaporkan fakta peristiwa. Mekanisme pengecekan akurasi dengan disiplin verifikasi, kebenaran berita dapat dipertanggungjawabkan.

Begitu pula dengan pemilihan angle harus bebas dari diintervensi. Penentuan sudut pandang yang dirumuskan dalam sidang redaksi bertujuan memilihkan berita yang terbaik buat publik dan sekaligus mempertegas misi media. Supaya leluasa dalam merumuskan konten, non-redaksi seperti bagian pemasaran, bagian iklan, dan bagian sirkulasi tidak dapat mempengaruhinya (Kovach \& Rosenstiel, 2003).

Budaya dalam rapat redaksi di media Tempo setiap perencaan konten, peserta diharusnya membawa ide yang diperoleh dari "belanja" informasi di lapangan. Tidak selalu gagasan yang diterima dalam rapat perencanaan berasal dari anggota redaksi yang memiliki jabatan struktural seperti redaktur eksekutif dan pemimpin redaksi. Tidak ada keitimewaan dalam rapat redaksi untuk jabatan struktural. Sering kali usulan yang diterima datang dari kalangan reporter atau redaktur. Setelah usulan diterima, kepala kompartemen selanjutnya menyiapkan pembabakan tulisan berdasarkan angle, pengecekan bahan, serta pembagian tulisan. Liputan investigasi Tempo sebagian besar berasal dari usulan para reporter. Ini memperlihatkan bahwa informasi awal dari rencana leputan investigasi diperoleh dan liputa lainnya dari lapangan, bukan permintaan dari atas.

Tidak melibatkan non-redaksi dalam rapat perencanaan sebagai bentuk penerapan pagar api (firewall) redaksi Tempo. Namun, tidak berarti redaksi mengabaikan aspirasi bagian penjualan iklan, bagian sirkulasi dan pemegang saham. Tarik menarik dua kepentingan bisnis dan redaksi tidak dapat dihindari. Di sinilah pentingnya penerapan pagar api. Redaksi dan bisnis yang sehari-hari berada dalam satu atap terbangun mekanisme kerja. Komprominya kedua pihak saling memahami peran masing masing.
Dalam menerapkan prinsip pagar api media di Indonesia telah mempunyai beleid berupa Undang Undang Nomor 40 Tahun 1999 tentang Pers dan Kode Etik Jurnalistik. Undang-undang ini antara lain memuat apa hak dan kewajiban media massa. Misalnya media harus terpisah jelas dan tegas membedakan artikel sebagai produk jurnalistik dan artikel produksi iklan. Teknis pemisahan antara kepentingan bisnis dan pemberitaan ini terdapat di Peraturan Dewan Pers (LPDS, 2019) Disebutkan setiap berita/artikel/isi yang merupakan iklan dan atau isi berbayar wajib mencantumkan keterangan advertorial, sponsored atau kode ads, iklan atau kata lain yang menjeslaskan bahwa konten tersebut adalah iklan.

Tempo sering menolak pemasangan iklan karena kontennya dianggap bertentangan dengan kepentingan publik atau menyudutkan hasil liputan investigasi awak redaksinya. Salah satu contoh iklan advertorial yang menganulir isi majalah Tempo mengenai adanya rekayasa proyek Kota Bandar Kemayoran pada April 2006 silam. Redaksi Tempo secara resmi menyampaikan permintaan maaf kepada pembaca karena kebobolan menayangkan iklan yang isinya mementahkan liputan investigasinya.

Ini membuktikan bahwa redaksi media massa dapat dinilai mampu menjaga independensinya dan bertanggung jawab kepada publik atas konten berita yang diproduksi. Manajemen Tempo meyakini bahwa sikap redaksi tidak akan berpengaruh terhadap mitra bisnis seperti pemasang iklan yang sumber utama pendapatan perusahaan. Persepsi publik bahwa redaksi media di era konglomerasi dan kemajuan teknologi informasi digital mudah dikendalikan oleh pemilik modal tidak sepenuhnya benar.

\section{Pembahasan}

Anggapan bahwa pengaruh bisnis dan juga pemilik perusahaan (ownership) serta politik pada ruang redaksi media sudah lama melakat dalam pandangan publik. Ukuran lama bukan dilihat dari kurun waktu tahun, 
melainkan sejak media massa arus utama (mainstream) baik surat kabar, televisi, radio dan lainnya, pertama kali terbit. Biasanya khalayak bertanya siapa pemilik media, dari grup perusahaan apa, dari mana sumber pendanaan diperoleh, dan banyak pertanyaan lain yang bernada mengorek. Ini menguatkan pandangan Maxisme bahwa media merupakan alat produksi masyarakat kapitalis yang dimiliki oleh kelas penguasa. Ini menjadikan khalayak menganggap wajar-wajar saja dan bukan perkara serius apabila media gampang dikendalikan.

Pandangan di atas sangat memprihatinkan. Sebab pengaruh penilaian yang cenderung menggeneralisasikan itu bertolak belakang dengan prinsip-prinsip dan tujuan pers didirikan. Tindakan intervensi atas produk pers dalam berbagai bentuk tidak dapat dibenarkan. Umumnya campur tangan pemilik perusahaan media dalam newsroom ingin memastikan konten yang dihasilkan selaras dengan konsentrasi bisnis dan kepentingan politiknya.

Fenomena tersebut jelas merupakan efek dari komersialisasi praktik ekonomi politik yang didominasi oleh kepentingan modal. Pasar media selain membidik pembaca juga iklan. Satu sisi media memperjuangkan kepentingan publik, di sisi lain media membutuhkan pendapatan dari produk komersiil dalam bentuk iklan. Sumber pendapatan media dari pembaca yang berlangganan sangat tidak memadai di era digital. Sedangkan iklan membuat media rentan mudah terpengaruh kepentingan eksternal. Konten akan didikte oleh para pengiklan yang berupaya tampil dominan. Lambat laum khalayak tergiring menerima begitu saja informasi yang disajikan media. Publik cenderung tidak peduli terhadap kualitas konten media (Mosco, 2006).

Campur tangan ke ruang redaksi bisa juga dipicu oleh persaingan, mengejar rating, atas nama kebutuhan publik, maupun permintaan sponsor. Idealisme newsroom menjadi miskin gagasan karena kalah dengan khalayak yang terpersuasi konsumerisme.
Kesan yang timbul, kini media telah menjadi kepanjangan tangan kepentingan pemilik modal. Produk media yang ditawarkan ke publik sebagai representasi struktur dominan. Kapasitas maupun potensi agen yang memiliki hubungan dengan struktur dikesampingkan.

Dalam teori struktitasi, kerja media dapat dilihat adanya pengaruh luar, yaitu negara baik melalui regulasi maupun praktik pemerintahannya. Media di Indonesia pernah mengalami intervensi bahkan represi saat era rezim Orde Baru bekuasa (Steele, 2007). Melalui aparat militer maupun sipil, negara semena-mena mengatur kepemilikan media hingga kontennya.

Dominasi kekuasaan Orde Baru pada media, dikenal dengan istilah "budaya telepon" di mana aparat menelepon redaktur sebuah media dengan tujuan melarang memberitakan suatu peristiwa yang dianggap merugikan negara. Intervensi ke ruang redaksi secara langsung seperti itu mendistorsi independensi media dalam menjalankan kemerdekaan pers (Kovach \& Rosenstiel, 2003).

Media massa di Indonesia mengalami banyak perubahan sejak akhir abad 20 hingga awal abad 21. Perubahan yang paling terasa adalah orientasi media dalam menjaga independensi dari pengaruh bisnis dan faktor lainnya seperti perkembangan teknologi. McQuail dalam buku Mass Communication Theory menyebutkan adanya tren aktivitas media di era digital yaitu saling terintegrasi secara global. Tren ini dalam pandangan kalangan Maxisme diartikan sebagai wujud bagaimana media mengedepankan kepentingan komersial guna mengejar profit.

Demi mendapat profit, budaya pop diasumsikan lebih penting diproduksi oleh media ketimbang memperjuangkan komitmen sosial seperti yang dikonstruksikan publik yaitu media harus kritis, adil, dapat dipercaya dan memihak kepada khalayak. Fenomena ini menguatkan analisis pemikiran Marxis bahwa media menjadi bagian dari dominasi kekuasaan dan dalam praktiknya turut menciptakan kesadaran semu. Melalui 
penciptaan kelas dominasi dan kelas yang didominasi, media menjadi alat yang dikuasai kemudian dipaksa menerima kepentingan penguasa.

Pengaruh modal mestinya dilihat dalam kerangka bisnis, bukan konten. Cara pandang ini penting untuk menjaga media tetap eksis dalam independensi. Sehingga antara agen dan struktur terjadi relasi saling menguatkan kesadaran pentingnya idealisme. Idealnya, media massa membangun dialektika antara agen sebagai aktor dan struktur secara dinamis dan prosesual (Giddens, 1990).

Dalam teori struturasi, titik tolaknya adalah tindakan manusia di mana setiap orang dalam praktik sosial dapat disebut sebagai aktor. Mereka dengan sadar menciptakan suatu cara atau kondisi yang berulang-ulang. Dalam koteks ruang pemberitaan media, peserta rapat redaksi adalah sebagai agen yang berkenpentingan menerapkan prinsip independen terhadap produk beritanya. Proses strukturasi ini berlangsung rutin dan dilakukan dengan penuh kesadaran.

Praktik rapat redaksi Tempo ketika merencanakan laporan utama atau cover majalah, hanya dihadiri oleh jajaran redaksi. Mereka terdiri dari reporter, redaktur hingga pemimpin redaksi ditambah bagian foto, visual, dan periset. Bagian non-redaksi dalam hal ini marketing, iklan, srikulasi bahkan pemegang saham tidak diundang. Kalaupun di antara mereka masuk ruang pemberitaan, wajib menjelaskan keperluannya.

Di sini menunjukkan bahwa tim redaksi Tempo yang merupakan agen sosial memperlihatkan otoritasnya. Wartawan kerap kali melihat sector bisnis berlawanan dengan independensi jurnalitik. Mereka mencemaskan produk iklan mempengaruhi akuntabilitas kualitas konten. Individu merupakan agen yang secara terus-menerus memproduksi struktur (Giddens, 1990). Maksudnya, individu mampu menciptakan perubahan tidak hanya struktur sosial sebagaimana dipahami dalam produksi dan reproduksi sistem sosial, tapi juga menciptakan sumber daya.

Pesatnya kemajuan teknologi digital Tempo dan sejumlah anak usahanya berupaya tetap memegang prinsip independensi. Upaya ini tidak mudah, banyak tantangan terutama terkait dengan model bisnis yang belum terlihat menguntungkan media di era digital sekarang. Satu sisi media konvensional yang dikelola Tempo -majalah dan koran-mengalami penurunan pendapatan. Sumber pemasukan utama dari sirkulasi maupun iklan turun drastis. Sedangkan pendapatan dari produk digital yang dibangun Tempo, belum bisa menutupi biaya produksi.

Strategi untuk tetap eksis Tempo telah ditopang oleh budaya kerja perusahaan yang mencerminkan nilai-nilai idealisme, yaitu terpercaya, merdeka dan profesional. Terpercaya didefinisikan menjunjung tinggi kejujuran, integritas dan konsistensi. Merdeka dimaksudkan memberi ruang kebebasan berfikir dan berekspresi. Sedangkan profesional diartikan memiliki kompetensi di bidangnya. Budaya kerja perusahaan ini dibuat secara bersama-sama, melibatkan semua perwakilan departemen dalam korporasi Tempo Media Group. Prosesnya cukup panjang. Untuk mencapai kesepakatan pentingnya nilai-nilai yang tercermin pada tiga kata di atas (terpercaya, merdeka dan profesional), perumusannya mengundang para ahli dan lembaga konsultan bisnis yaitu Jakarta Consulting Group.

Selain budaya kerja perusahaan, faktor yang mendorong terjaganya independensi adalah struktur kepemilikan perusahaan. Tempo Media Group dengan induk perusahaan PT Tempo Inti Media Tbk, merupakan perusahaan swasta terbuka. Sahamnya dimiliki beberapa institusi dan sebagian masyarakat atau publik. Selain PT Tempo Inti Media Tbk, pegang saham lain adalah PT Grafiti Pers, PT Jaya Raya, Yayasan Jaya Raya, Yayasan Karyawan Tempo, Yayasan 21 Juni dan masyarakat. 
Tabel 1. Komposisi pemegang saham Tempo Media Group per 30 April 2020

\begin{tabular}{|c|c|c|c|}
\hline Nama & Jumlah Saham & Jumlah Modal & $\begin{array}{c}\text { Persentas } \\
e\end{array}$ \\
\hline $\begin{array}{l}\text { Yayasan Seni Budaya Olahraga } \\
\text { Pembangunan Jaya Raya }\end{array}$ & 90.429 .394 & Rp. 9.042 .939 .400 & $8,54 \%$ \\
\hline Yayasan Tempo 21 Juni 1994 & 181.322 .500 & Rp. 18.132.250.000 & $17,13 \%$ \\
\hline PT. Grafiti Pers & 256.960 .003 & Rp. 25.696 .000 .300 & $24,28 \%$ \\
\hline Yayasan Karyawan Tempo & 87.627 .267 & Rp. 8.762 .726 .700 & $8,28 \%$ \\
\hline PT.Jaya Raya Utama & 172.329 .205 & Rp. 17.232.920.500 & $16,28 \%$ \\
\hline Masyarakat & 269.664 .881 & Rp. 26.966.488.100 & $25,49 \%$ \\
\hline Total & 1.058 .333 .250 & Rp. 105.833.325.000 & $100.00 \%$ \\
\hline
\end{tabular}

Sumber: website korporasi PT Tempo Inti Media Tbk, 2020.

Dari komposisi saham pada tabel 1 tidak satupun instansi, yayasan serta individu menguasai 51 persen saham Tempo. Dalam prosentase tercatat saham masyarakat paling besar yaitu 25,49 persen, Sedangkan pemegang saham korporasi dan yayasan berkisar 8 sampai 24 persen. Tidak ada saham pribadi baik dari elite Tempo maupun orang luar. Sehingga dengan komposisi demikian kendali penguasaan perusahaan bersifat kolegial.

Pengusaha Ciputra (almarhum) yang disebut-sebut memiliki saham Tempo ternyata tak selembarpun punya saham pribadi langsung. Ciputra mempunyai saham di Tempo melalui Yayasan Jaya Raya, sebuah organisasi yang mengurus kegiatan olahraga. Di yayasan ini Ciputra punya 10 persen saham. "Ciputra sebenarnya ingin terlibat, tapi ia tidak berani. Dia berusaha tapi tidak pernah berhasil," kata Goenawan Mohamad, pendiri Tempo (Steele, 2007).

Menurut peneliti, inilah yang membuat Tempo tidak mudah diintervensi. Tempo kuat menjaga independensi karena keputusan tertinggi produk berita ada di forum rapat redaksi. Pemegang saham tidak mendapat kursi dalam ruang redaksi. Kalaupun mencoba intervensi dengan memanfaatkan jabatan pemimpin redaksi yang notabene diangkat oleh dewan direksi, biasanya akan terungkap dalam rapat perencanaan redaksi. Para aktor awak redaksi merupakan agen yang produksi berita dan sebagai sumber utama pemasok informasi ruang pemberitaan.

\section{SIMPULAN}

Dapur redaksi media yang independen terbangun berkat saling memanfaatkan kuatnya relasi agen dan struktur di dalamnya. Agen dan struktur sebagai dualitas yang saling mempengaruhi sebagai ciri khas praktik strukturasi ini tercipta lewat budaya kerja organisasi. Sedangkan aspek ekonomi politik, korporasi yang merupakan perusahaan terbuka di mana tidak ada dominasi pemegang saham atau pemagang saham mayoritas. Sehingga secara operasional ruang pemberitaan sepenuhnya dalam kendali tim redaksi. 
Dari sisi teori, korporasi Tempo Media Group lebih mudah dan leluasa menentukan mitra bisnis sesuai dengan visi dan misi perusahaan. Namun, dari sisi bisnis korporasi media ini harus menanggung risiko kehilangan peluang pendapatan ketika harus menolak iklan yang berhubungan dengan konten pemberitaan. Redaksi Tempo dapat menentukan (menveto) pemasangan iklan yang isinya dianggap bertentangan atau mereduksi sikap redaksi. Ini terutama bagi pengiklan yang memiliki masalah hukum atau kasus yang sedang disorot media Tempo.

Praktik keredaksian Tempo dalam teori strukturasi bisa disimpulkan adanya dua sumber daya yaitu autoritatif dari hasil kesepakatan aktivitas agen dan sumber daya alokatif yang merupakan control atau pengawasan atas mutu produk. Menurut teori strukturasi bilamana agen memiliki kuasa terhadap produksi, berarti juga melakukan tindakan reproduksi sistem atau strutur. Dengan demikian, kebijakan Tempo Meida Group telah menerapkan praktik strukturasi di semua jaringan anak perusahaan untuk memenuhi kebutuhan khalayak terkait dengan idealisme media dan juga kelangsungan bisnisnya.

Di tengah derasnya pengaruh teknologi digital, Tempo memang dihadapkan pada persoalan prospek bisnis. Prospek usaha ini tidak hanya untuk majalah, kotan dan portal berita, tapi juga untuk media baru dalam korporasi Tempo yang 100 persen memanfaatkan paltform digital. Faktor lainnya yaitu model bisnis media di era digital, belum ada rujukan yang dapat dijadikan ukuran sukses. Meski demikian, media mainstream atau media arus utama tetap dituntut profesional, obyektif, dan independen.

Berdasarkan analisa dan kesimpulan tersebut, sangat disarankan prinsip-prinsip independensi media Tempo tetap dipertahankan. Sebab tidak semua media sanggup mempraktikkan independensi secara konsisten. Ini kekuatan Tempo yang sudah lama dibangun dan menjadi budaya perusahaan. Profesionalisme wartawan Tempo merupakan aset utama sekaligus menjadi agen sosial untuk membangun keseimbangan pengaruh antara politik kekuasaan, kepentingan publik, dan bisnis. Apabila ketiganya berkongsi membangun kekuatan, maka dengan mudah akan mendominasi tatanan sosial. Di sinilah perlunya prinsip independen media dipertahankan dalam payung hukum kebebasan pers yang dilindungi undang-undang.

\section{DAFTAR PUSTAKA}

Adila, I. \& Prasetya, A.B. (2020). Ekonomi Politik Komunikasi, Sebuah Realitas Industri Media di Indonesia. Malang, UB Press.

Aminah, S. \& Roikan. (2019). Pengantar Metode Penelitian Kualilatif Ilmu Politik. Jakarta: Prenadamedia Group.

Atmakusumah. (2018). Pers Ideal Untuk Masa Demokrasi. Jakarta: LPDS

Bungin, B. (2017). Metode Penelitian Kualitatif: Aktualisasi Metodologis ke Arah Ragam Varian Kontemporer. Depok: Rajawali Pers.

Giddens, A. (1990). Central Problems in Social Theory, London: Macmillan Education Ltd $\mathrm{H}$.

KBBI Daring. Kemdikbud.go.id

Kepemilikan saham PT Tempo Inti Media, Tbk. (2020, 30 April). Diakses dari situs https://korporat.tempo.co.id

Kovack, B. \& Rosenstiel, T. (2003). Sembilan Elemen Jurnalisme, Terjemahan: Pareanom. Jakarta: Yayasan Pantau.

Kovack, B. \& Rosenstiel, T. (2012). Blur, Bagaimana Mengetahui Kebenaran di Era Banjir Informasi. Terjemahan: Yayasan Pantau. Jakarta: Dewan Pers.

LPDS. (2019). Pedoman Uji Kompetensi Wartawan, Penerapan Standar Kompetensi Wartawan. Jakarta: Lembaga Pers Dr. Soetomo Yayasan Pendidikan Multimedia Adinegoro. 
McQuail. D. (2018). Teori Komunikasi Mssa, Terjemahan: Iva Izzati. Jakarta: Salemba Humanika.

Mosco, V. (2006). The Political Economy of Communication, London: Sage Publication.

Musfialdy. (2019). Independensi Media: ProKontra Obyektivitas dan Netralitas Pemberitaan Media. Jurkom. Jurnal Riset Komunikasi, 2 (1). https://doi.org/10.24329/jurkom.v2i1 .50 .

Steele, J. (2007). Wars Within, Pergulatan Tempo, Majalah Berita Sejak Zaman Orde Baru. Jakarta: Dian Rakyat.

Subandi, Z.E. \& Sadono, T.P. (2018). Komodifikasi, Spasialisasi, dan Strukturasi dalam Media Baru di Indonesia. Jurnal Universitas Bunda Mulia.

http://dx.doi.org/10.30813/ncci.v0i0. 1297.

Pratopo, W.M. (2017). Komodifikasi Wartawan di Era Konvergensi: Studi Kasus Tempo. Jurnal Komunikasi
Indonesia,

2615-2894. https://doi/org/10.7454/jki.v6i2.8715

Putra, A.M., Nugroho, H. \& Budiawan. (2016). Ekonomi Politik Pemberitaan Konflik Persepakbolaan Indonesia. Jurnal Ilmu Komunikasi, 13 (2). https://doi.org/10.24002/jik.v13i2.67 3.

Sudibyo, A. (2000). Absennya Pendekatan Ekonomi Politik Untuk Setudi Media. Jurnal Ilmu Sosial dan Ilmu Politik, Vol. 4-2, 115-134. Universitas Gadjah Mada.

Tracy, S. J. (2013). Qualitative Research Methods Collecting Evidence, Crafting Analysis, Communicating Impact. London: John Wiley \& Sons, Ltd, The Atrium, Southern Gate, Chichester, West Sussex, PO19 8SQ, UK.

Yin. K. R. (2003). Case Study Research: Design and Methods. 3th Editon. America SAGE Publication 